\title{
SISTEM PENDAFTARAN RAPID TEST COVID-19 PADA KLINIK MEDIKA PALANGKA RAYA
}

Putu Bagus Adidyana Anugrah Putra ${ }^{\text {a,1,* }}$

${ }^{a}$ Universitas Palangka Raya, Jalan Hendrik Timang, Palangka Raya, kalimantan Tengah, Indonesia

1 putubagus@it.upr.ac.id*;

* corresponding author

\section{ARTICLE INFO}

Keywords

Covid-19

Waterfall

ERD

DFD

\section{ABSTR ACT}

During January-April 2020, a number of flights were canceled to reduce the risk of contracting COVID-19. Flights were reopened when the government relaxed the PSBB in mid-May 2020. However, aviation activities must comply with health protocols. One of the requirements for traveling by plane is to show a letter of negative PCR test results for COVID-19 or rapid test with non-reactive results. The medical clinical laboratory in registering the rapid test is still manual so that the general public who wants to travel by plane in carrying out a rapid test must be served from registration to completion at the clinic. So that sometimes there is an accumulation of people who want a rapid test. It is necessary to make a registration system for rapid tests in medical clinics using the waterfall method. The stages of system development are business process modeling using Data Flow Diagrams (DFD) and Entity Relationship Diagrams (ERD), user interface design, and the testing process will be carried out with a blackbox. The system developed can reduce the accumulation of patients in the clinic. From the test results, the system functionality can run well.

\section{Pendahuluan}

Kesehatan merupakan salah satu aspek penting dalam kehidupan masyarakat. Kesehatan juga merupakan salah satu indikator untuk mengukur tingkat kebahagiaan, keamanan, dan kesejahteraan masyarakat. Dengan kesehatan yang baik, maka masyarakat dapat melakukan berbagai aktivitas secara optimal. Namun, seiring berubahnya pola kehidupan masyarakat, kesehatan masyarakat menjadi terganggu. Salah satu faktor yang mempengaruhi kesehatan masyarakat adalah pelayanan kesehatan.

Penerbangan memegang peranan penting bagi negara. Selain mampu mengakomodasi mobilitas penduduk dan logistik, penerbangan juga memiliki dampak berkelanjutan terhadap sektor pariwisata dan ekonomi. Sayangnya, belakangan ini sektor penerbangan mengalami kelesuan. Sepanjang Januari-April 2020, sejumlah penerbangan dibatalkan demi mengurangi risiko penularan COVID-19. Akibatnya, industri penerbangan kehilangan pendapatan senilai Rp 207 miliar[1]. Penerbangan kembali dibuka ketika pemerintah melonggarkan PSBB (Pembatasan Sosial Berskala Besar) pada pertengahan Mei 2020. Kendati demikian, aktivitas penerbangan harus menaati protokol kesehatan yang mengacu pada Surat Edaran (SE) No.7 Tahun 2020[2]. Salah satu syarat berpergian menggunakan pesawat adalah menunjukkan surat hasil uji PCR negatif COVID-19 atau rapid test dengan hasil non-reaktif.

Laboratorium Klinik Medika menjadi salah satu pusat pelayanan kesehatan di Palangka Raya merupakan salah satu klinik kesehatan yang sedang dikembangkan dengan jumlah pasien yang cukup banyak. Ditambah lagi dengan adanya masyarakat yang ingin melakukan rapid test sebagai salah satu syarat untuk berpergian. Laboratorium klinik medika dalam pendaftaran rapid test masih secara manual sehingga, masyarakat umum yang hendak berpergian menggunakan pesawat dalam melakukan rapid test harus dilayani mulai dari pendaftaran hingga selesai di klinik. Sehingga 
terkadang terjadi penumpukan masyarakat yang ingin rapid test. Berdasarkan permasalah tersebut, perlu dibuat suatu sistem pendaftaran online menggunakan bahasa pemrograman php untuk pendaftaran rapid test pada klinik medika sehingga penumpukan masyarakat di klinik bisa dihindari.

\section{Metodologi Penelitian}

Model yang digunakan merupakan suatu hasil dari siklus hidup pengembangan perangkat lunak model waterfall [3] yaitu pada tahap analisis, desain, implementasi dan pengujian. Berikut ini merupakan beberapa tahapan penelitian, yaitu:

1) Studi Pustaka dan Observasi

Metode ini melakukan studi pustaka terhadap buku, jurnal ilmiah nasional dan internasional sebagai pendukung dalam penelitian.[4] Observasi dilakukan untuk mengambil data-data untuk titik dan berapa besar radius yang diperlukan untuk menandakan suatu ruangan yang nantinya akan dijadikan area untuk mengeluarkan informasi.

2) Analisis Sistem

Proses pencarian kebutuhan difokuskan pada software untuk mengetahui sifat dari aplikasi yang akan dibuat, pemodelan proses bisnis menggunakan Data Flow Diagram (DFD) dan Entity Relationship Diagram (ERD).[5] [6]

3) Desain Sistem

Proses ini digunakan untuk membuat blueprint software seperti, perancangan basis data dan perancangan interface.[7][8]

4) Implementasi

Proses ini akan dilakukan pembuatan perangkat lunak sesuai dengan perancangan basis data dan antar muka yang telah dilakukan pada tahap sebelumnya.[9]

5) Pengujian Sistem

Proses pengujian akan dilakukan dengan blackbox testing. Pengujian blackbox adalah pengujian aspek fundamental sistem untuk menguji dan melihat kesalahan yang ada pada program maupun fungsi dari system.[10]

\section{Hasil dan Pembahasan}

\subsection{Proses Bisnis Sistem}

Flowchart adalah ilustrasi visual yang menggambarkan alur kerja atau proses serta solusi dari sebuah kajian atau permasalahan. Flowchart kerap digunakan untuk menjelaskan konsekuensi logis, proses proyek, dan alur otoritas dalam sebuah organisasi. Selain itu, flowchart juga digunakan untuk menjelaskan alur kerja.[11] Gambar 1 merupakan flowchart dari system yang dibuat. 


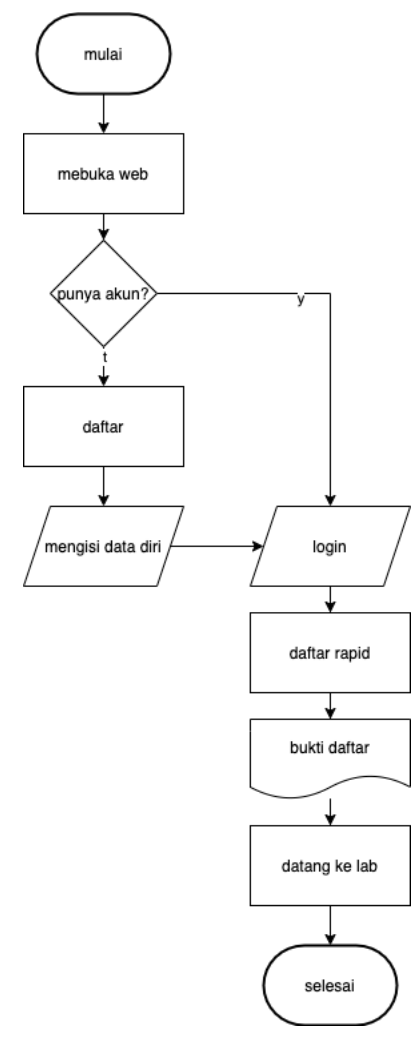

Gambar 1. Flowchart Sistem

\subsection{Data Flow Diagram (DFD)}

Dalam proses perancangan sistem diawali dengan tahap perancangan diagram konteks. Diagram konteks adalah diagram yang paling atas terdiri dari suatu proses dan menggambarkan ruang lingkup sistem. Berikut diagram context, dfd level 1 dan dfd level 2 dari sistem yang akan dibuat :

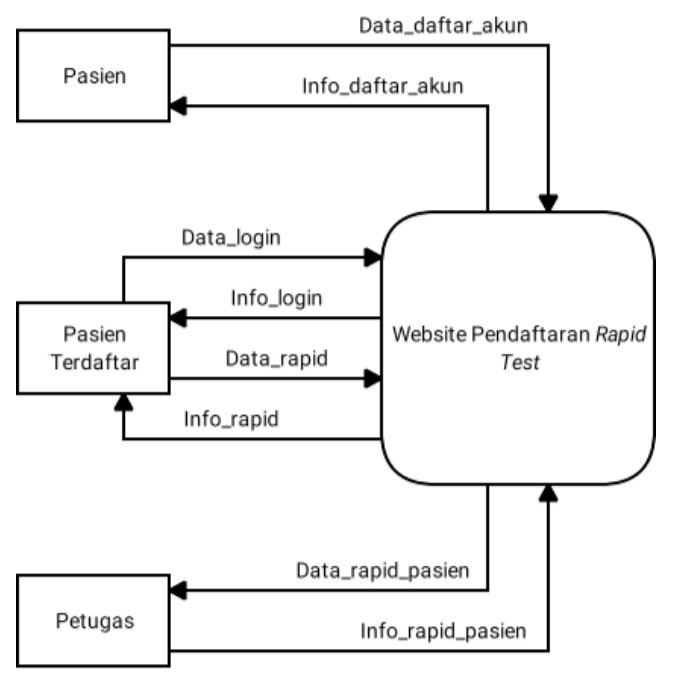

Gambar 2. Diagram Context 


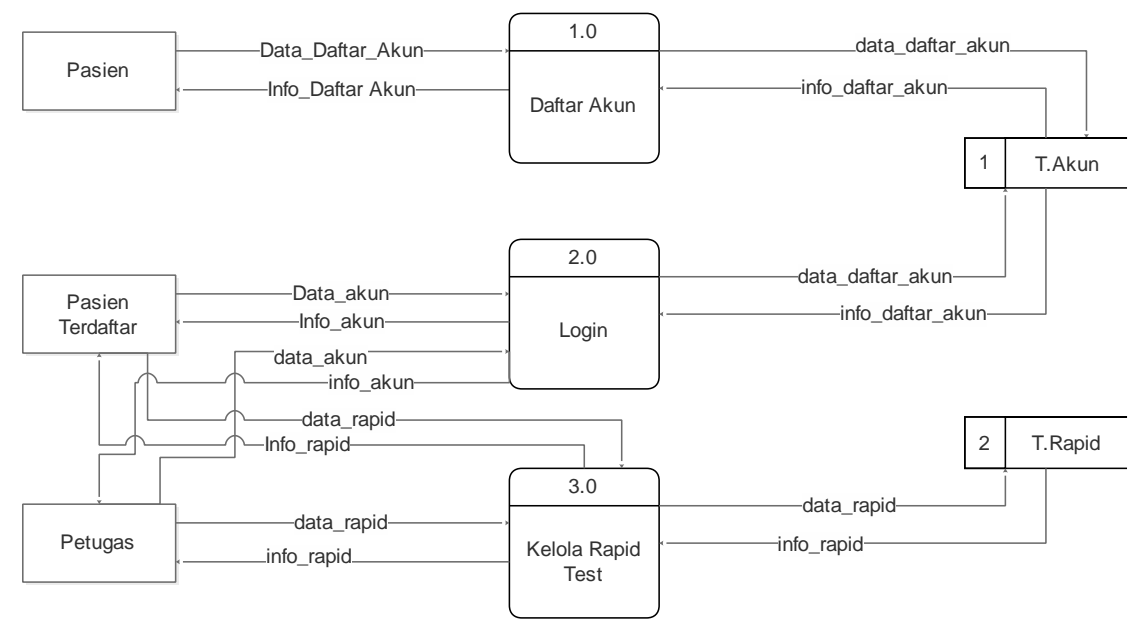

Gambar 3. DFD Level 1

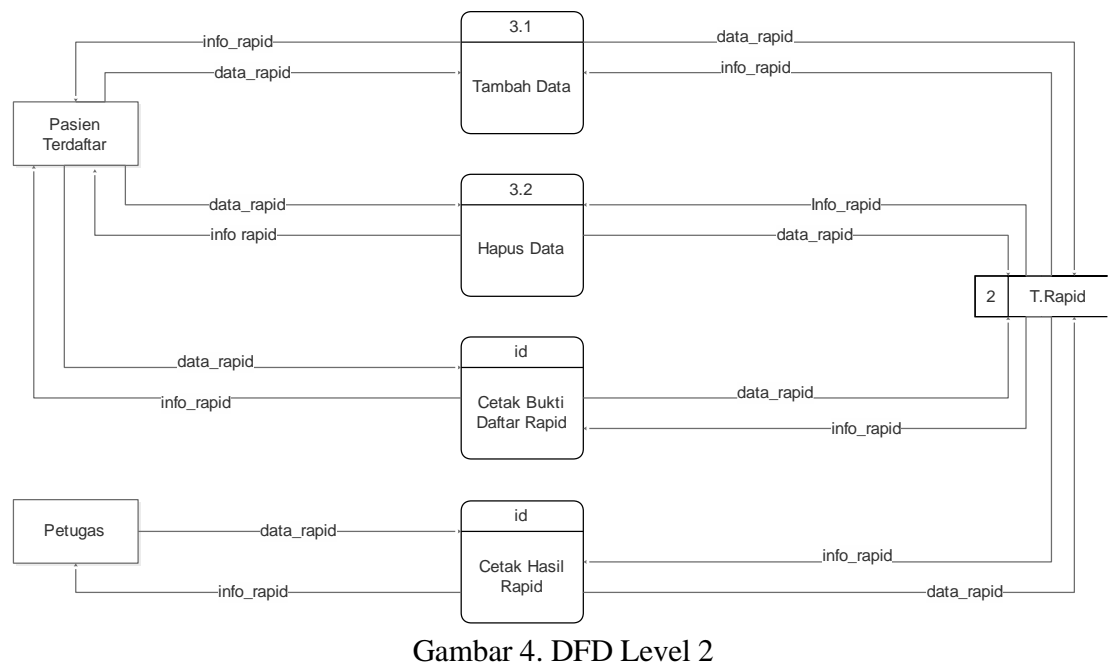

Untuk menggunakan sistem pendaftaran rapid test ini pasien harus membuat akun terlebih dulu. Pasien harus login untuk melakukan pendftaran rapid test Jika verifikasi login valid maka pasien mempunyai hak akses melakukan pendaftaran rapid test di lab dan mengelola akunnya sendiri. Ketika pasien sudah melakukan pendaftaran rapid test, pasien mendapat bukti pendaftaran. Petugas mengkonfirmasi/memverifikasi bukti pendaftaran melakukan rapid test dari pasien.

\subsection{Entity Relationship Diagram (ERD)}

Entity Relationship Diagram (ERD) merupakan gambaran data yang dimodelkan dalam suatu diagram yang digunakan untuk mendokumnetasikan data dengan cara menentukan apa saja yang terdapat dalam tiap entity dan bagaimana hubungan entity satu dengan yang lainnya. ERD digunakan untuk menunjukkan hubungan antara entity dengan database dan objek-objek (himpunan entitas) apa saja yang inign di libatkan dalam sebuah basis data.

Berikut ini merupakan ERD dari sistem yang dibuat. ERD yang berisi komponen-komponen himpunan entitas dan himpunan relasi yang masing-masing dilengkap dengan beberapa attribut yang mempresentasikan seluruh fakta yang ditinjau dari keadaan yang nyata. Sehingga dapat digambarkan secara lebih sistematis dengan menggunakan ERD. 


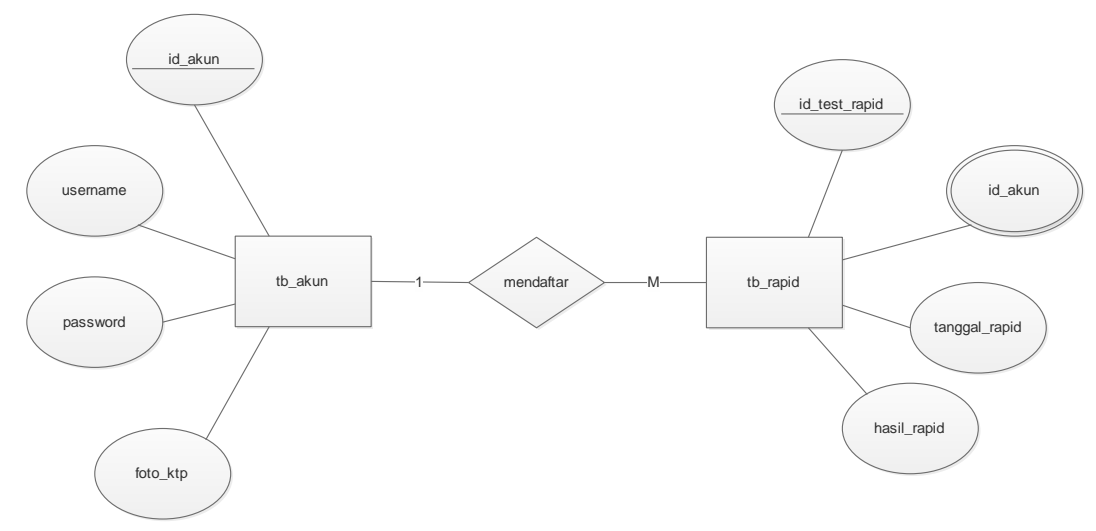

Gambar 5. Entity Relationship Diagram (ERD)

\subsection{Desain User Interface}

Desain antar muka pengguna (user interface) merupakan bentuk tampilan grafis yang berhubungan langsung dengan pengguna. Antar muka pengguna berfungsi untuk menghubungkan antara pengguna dengan sistem, sehingga komputer tersebut bisa digunakan oleh pengguna.

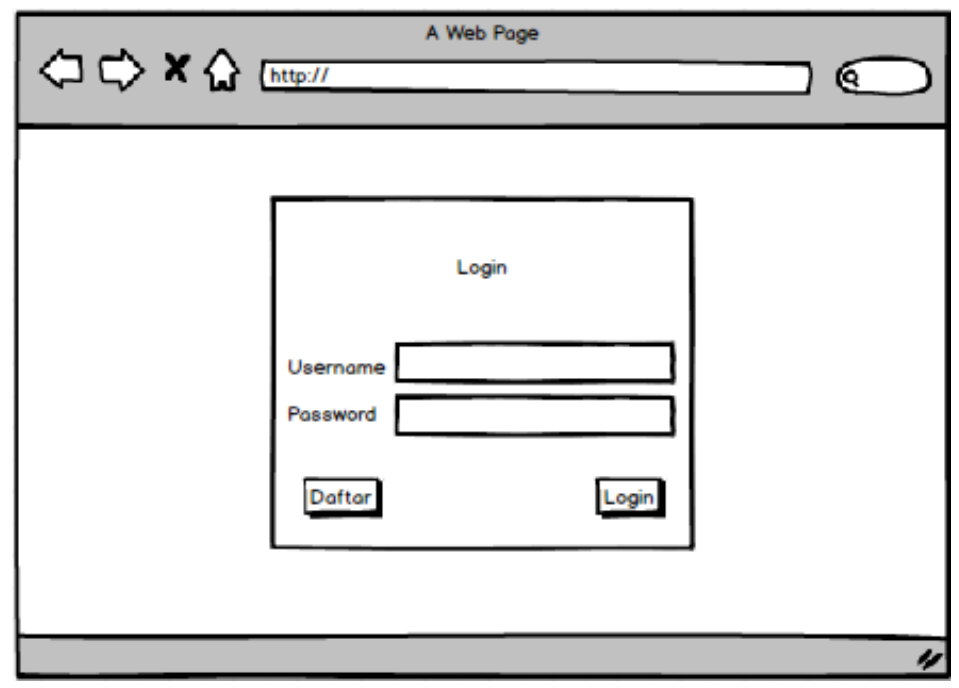

Gambar 6. Desain Interface Halaman Login

Gambar 6 merupakan desain halaman login sistem merupakan tampilan awal pada saat sistem baru dibuka pengguna sistem harus melakukan login terlebih dahulu untuk dapat masuk ke dalam sistem. 


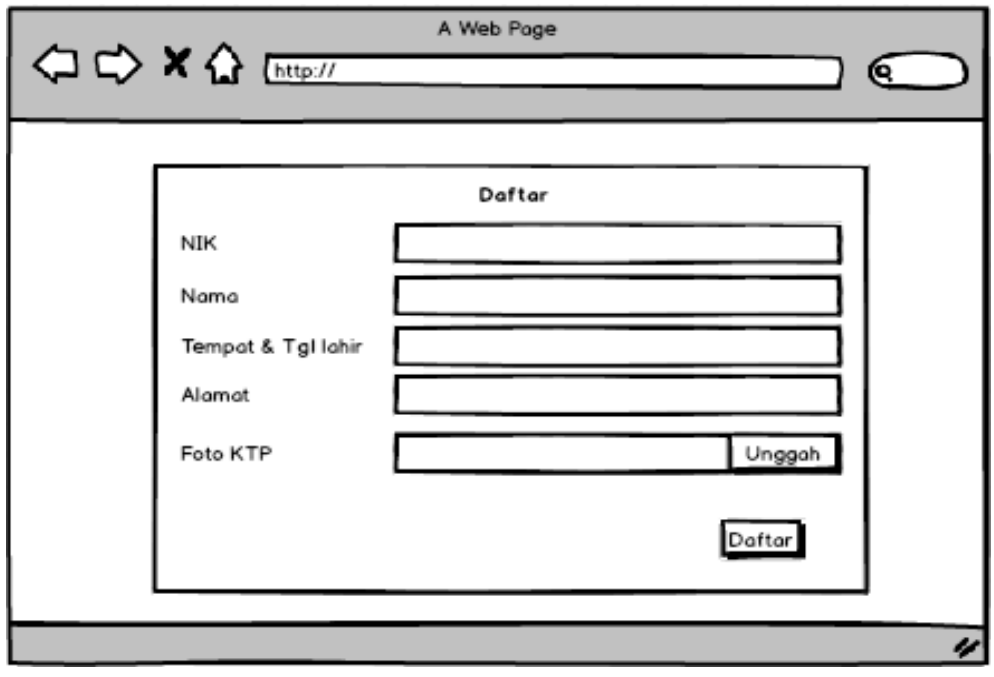

Gambar 7. Desain Interface Daftar Akun Pasien

Gambar 7 merupaka desain halaman daftar akun digunakan untuk pasien yang belum mempunyai akun.

\subsection{Implementasi}

Tahap implementasi merupakan tahap di mana desain basis data ataupun desain interface yang telah dibuat sebelumnya diterjemahkan ke dalam kode-kode dengan menggunakan bahasa pemrograman. Berikut merupakan tampilan implementasi system:

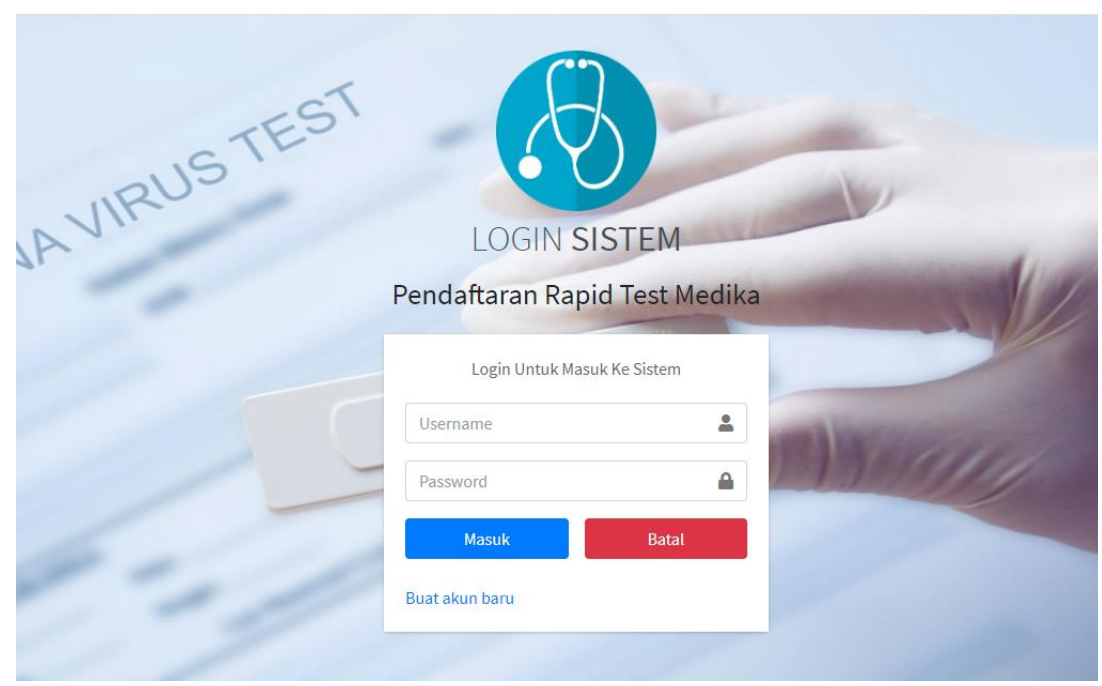

Gambar 8. Halaman Login

Gambar 8 merupakan implementasi untuk halaman pendaftaran akun bagi pendaftar rapid test. 


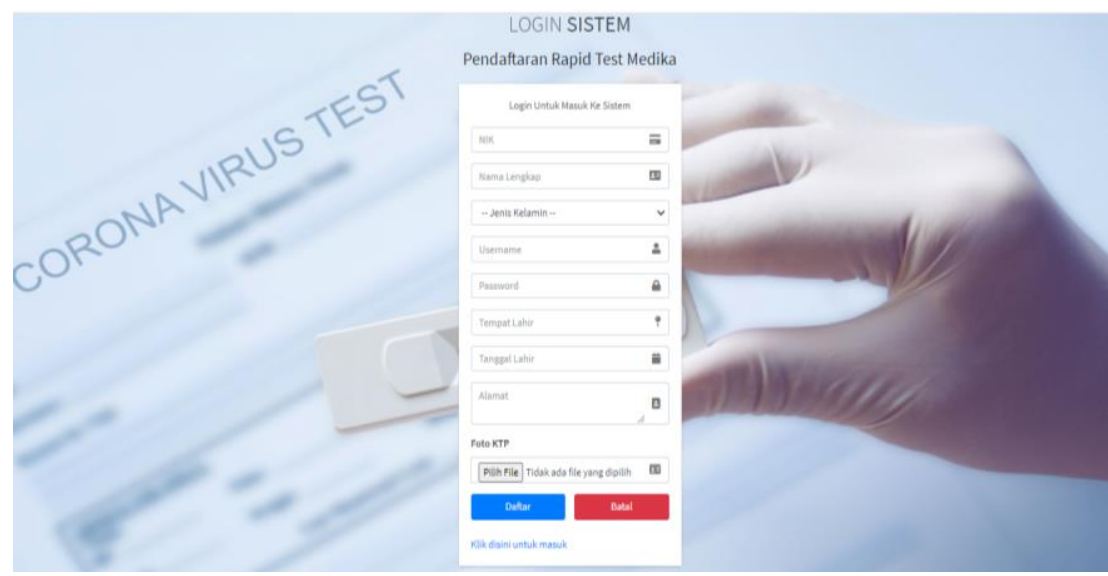

Gambar 9. Halaman Pendaftaran

Gambar 9 merupakan implementasi halaman untuk pendaftaran rapid test.

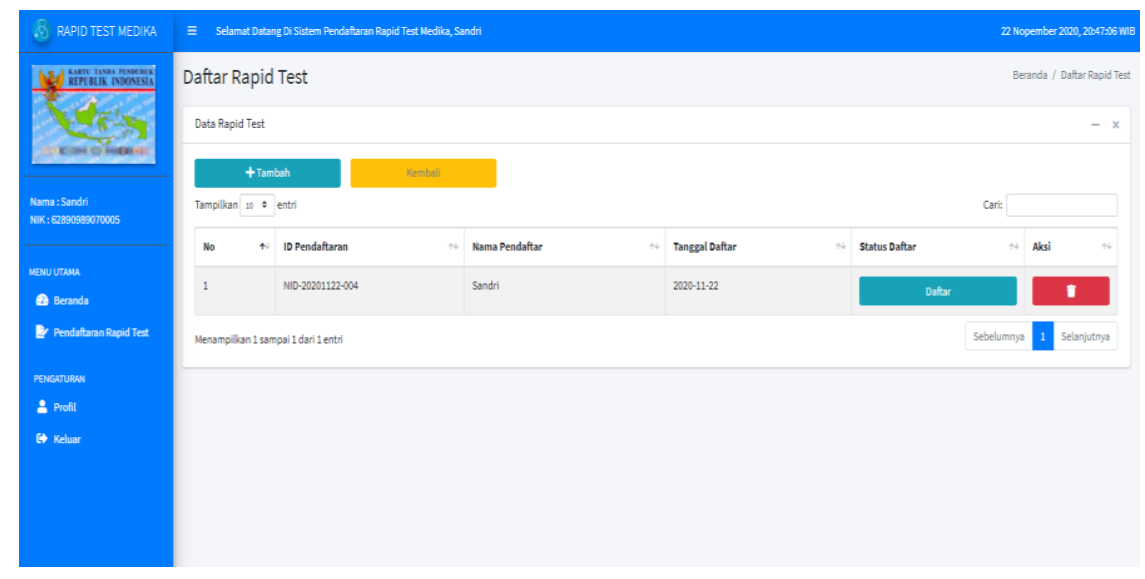

Gambar 10. Halaman Daftar Rapid Test

Gambar 10 merupakan implementasi halaman daftar.

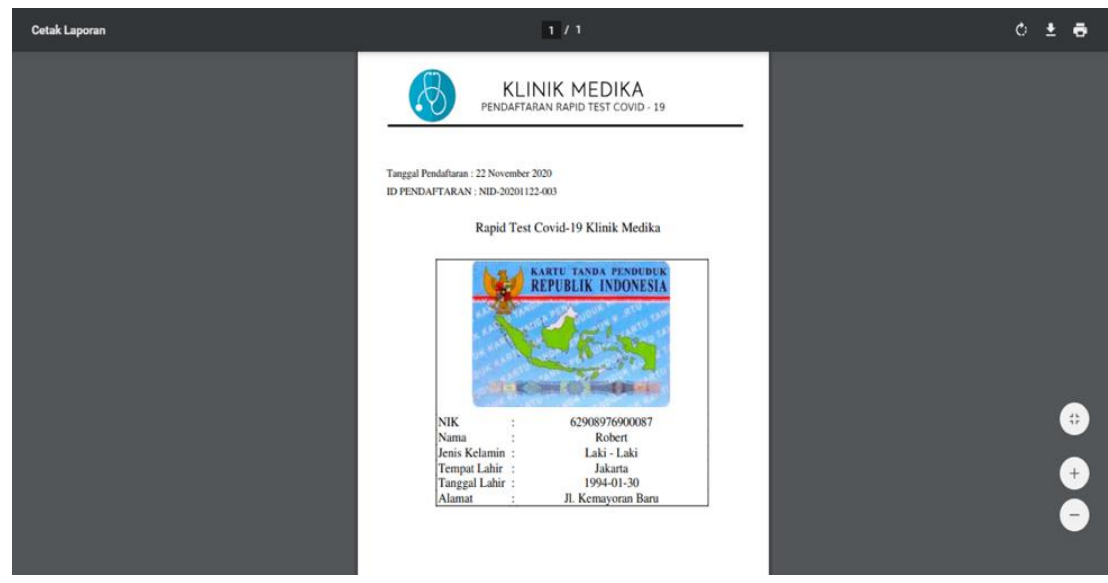

Gambar 11. Halaman Cetak Folmulir

Gambar 11 merupakan implementasi halaman cetak formulir pendaftaran. 


\subsection{Pengujian}

Penyatuan unit program kemudian uji secara keseluruhan. Pengujian yang dilakukan untuk sistem ini adalah black box testing. Pengujian blackbox digunakan untuk mengetahui seluruh fungsi secara spesifik dari sistem ini, apakah sudah berjalan dengan baik atau tidak.

\begin{tabular}{|c|c|c|c|c|}
\hline No & Kondisi Awal & Kondisi Yang Diinginkan & Kondisi Hasil & Hasil \\
\hline 1. & $\begin{array}{l}\text { Input alamat sistem } \\
\text { halaman }\end{array}$ & Menampilkan halaman login & $\begin{array}{l}\text { Menampilkan halaman } \\
\text { login }\end{array}$ & $\sqrt{ }$ \\
\hline 2. & Buat Akun & Akun berhasil dibuat & Akun berhasil dibuat & \\
\hline 3. & Login & Masuk ke halaman beranda & $\begin{array}{l}\text { Masuk ke halaman } \\
\text { beranda }\end{array}$ & $\sqrt{ }$ \\
\hline 4. & $\begin{array}{l}\text { Klik menu pendaftaran } \\
\text { rapid test }\end{array}$ & $\begin{array}{l}\text { Masuk ke halaman } \\
\text { pendaftaran rapid test }\end{array}$ & $\begin{array}{l}\text { Masuk ke halaman } \\
\text { pendaftaran rapid test }\end{array}$ & $\sqrt{ }$ \\
\hline 5. & Klik tombol Tambah & $\begin{array}{l}\text { Masuk ke halaman tambah } \\
\text { permintaan rapid test }\end{array}$ & $\begin{array}{l}\text { Masuk ke halaman } \\
\text { tambah permintaan } \\
\text { rapid test }\end{array}$ & $\sqrt{ }$ \\
\hline 6. & Klik tombol Daftar & Pendaftaran terkirim & Pendaftaran terkirim & $\sqrt{ }$ \\
\hline 7. & Klik menu Profil & $\begin{array}{l}\text { Masuk ke halaman profil } \\
\text { admin }\end{array}$ & $\begin{array}{l}\text { Masuk ke halaman } \\
\text { profil admin }\end{array}$ & $\sqrt{ }$ \\
\hline
\end{tabular}

Berdasarkan hasil pengujian sistem yang telah dilakukan, didapatkan hasil bahwa pada halaman admin semua proses dan error handling telah berfungsi dengan baik, sama halnya pada halaman untuk pendaftar. Semua proses dan aksi yang dilakukan di dalam sistem sudah sesuai dengan apa yang diharapkan. Sistem mampu menerima pendaftaran yang dilakukan secara online, menampilkan riwayat tes rapid serta menampilkan data pendaftar. Sistem pun dapat diterima dengan baik oleh pengguna.

\section{Kesimpulan}

Dalam pembuatan system pendaftaran rapid test digunakan metode pengambangan perangkat lunak waterfall. Tahapan awal yang dilakukan adalah melakukan analisis kubutuhan yang akan digunakan dalam sistem. Tahap selanjutnya membuat flowchart proses bisnis sitem, membuat desain ERD (Entity Relationship Diagram), desain alur data dengan DFD (Data Flow Diagram) dan desain interface. Untuk pengujian sistem dilakukan dengan menggunakan metode blackbox testing. Dari hasil pengujian dapat ditarik kesimpulan bahwa secara fungsionalitasnya, system dapat berjalan dengan baik.

\section{Daftar Pustaka}

[1] Kusmana, H. R. 2020. Aplikasi Paman Uco (Praktis Aman Uji Covid) Sebagai Inovasi Layanan Uji Pcr Berbasis Ehrs (Electronic Health Record System) Bagi Calon Penumpang Pesawat Dalam Rangka Menyongsong Masa Depan Indonesia Pasca Pandemi. Researchgate.

[2] Gugus Tugas Percepatan Penanganan Covid-19. Surat Edaran (SE) No.7 Tahun 2020. Kreteria dan Persyaratan Perjalanan Orang Dalam Masa Adaptasi Kebiasaan Baru Menuju Masyarakat Produktif Dan Aman Corona Virus Disease 2019 (Covid-19)

[3] Pressman, S. Roger. 2010. Pendekatan Praktisi Rekayasa.Perangkat Lunak.Edisi 7. Penerbit Andi. Yogyakarta. Halaman $45-.46$

[4] Sari, N. N. K., Putra, P. B. A. A., dan Widiatry,W. 2020. Sistem Informasi Kepegawaian UPT Kesatuan Pengelolaan Hutan Produksi Kapuas Tengah UNIT XI. Jurnal Informatika. Vol 7, No 2, Agustus 2020

[5] Putra, P. B. A. A., Sari, N. N. K dan Pranatawijaya, V. H. 2017. Analisis Dan Desain Sistem Monitoring Konsultasi Bimbingan Kartu Rencana Studi (KRS). Jurnal Teknologi Informasi. Volume 11, Nomor 1, Januari 2017 
[6] Pranatawijaya, V. H., Putra, P. B. A. A dan Gunawan, V. A. 2016. Pengembangan Perangkat Lunak Generate File Untuk Migrasi Data EPSBED Ke Format Table Feeder PDDIKTI. Jurnal Saintekom, Vol 6, No. 2, September 2016

[7] Pranatawijaya, V. H., Putra, P. B. A. A., Widiatry, W dan Sari, N. N. K. 2018. Pengembangan Perangkat Lunak Generate File Akun Uang Kuliah Tunggal (UKT) Universitas Palangka Raya. Jurnal Saintekom, Vol 6, No. 2, September 2018

[8] Putra, P. B. A. A., Pranatawijaya, V. H., Widiatry, W., Lisa. 2017. Rancang Bangun Sistem Informasi Pencarian Data Mahasiswa Dan Dosen Pada Fakultas Hukum Universitas Palangka Raya. Jurnal Teknologi Informasi. Volume 11, Nomor 2, Agustus 2017

[9] Sari, N. N. K., Putra, P. B. A. A., dan Christian, E. 2019. Rancang Bangun Aplikasi Mobile Learning Tenses Bahasa Inggris. Volume 13, Nomor 2, Agustus 2019

[10] Pranatawijaya, V. H., Putra, P. B. A. A., Widiatry, W dan Sari, N. N. K. 2019. Sistem Informasi Geografis Mencari Rute Lokasi Travel DiKota Palangka Raya Berbasis Sistem. Jurnal Teknologi Informasi. Volume 13, Nomor 1, Januari 2019

[11] Pranatawijaya, V. H., Widiatry, W., Priskila, R., dan Putra, P. B. A. A., 2019. Penerapan Skala Likert dan Skala Dikotomi Pada Kuesioner Online. Jurnal Sains dan Informatika. Volume 5, Nomor 2, November 2019 